\title{
ANALISIS KEMAMPUAN PEMAHAMAN MATEMATIS MAHASISWA PADA MATA KULIAH TEORI BILANGAN
}

\author{
Abdul Karim ${ }^{1}$, Arfatin Nurrahmah² \\ 1. Program Studi Pendidikan Matematika Universitas Indraprasta PGRI Jakarta \\ 2. Program Studi Pendidikan Matematika Universitas Indraprasta PGRI Jakarta \\ E-mail: abdul.depok@gmail.com
}

\begin{abstract}
ABSTRAK
Kurangnya pemahaman mahasiswa terhadap konsep-konsep yang diberikan serta mahasiswa masih mengalami kesulitan dalam mengidentifikasi apa yang diketahui dan apa yang akan dibuktikan. Penelitian ini bertujuan untuk menganalisis kemampuan pemahaman matematis mahasiswa dalam matakuliah teori bilangan. Metodologi penelitian yang digunakan menggunakan menggunakan metode penelitian deskriptif kualitatif. Subjek penelitian yang digunakan dalam penelitian ini berjumlah 30 responden. Teknik pengumpulan data menggunakan studi kepustakaan, dokumentasi dan wawancara. Hasil penelitian kemampuan pemahaman matematis dari dua indikotor penelitian yaitu kemampuan pemahaman konseptual dan kemampuan pemahaman fungsional, sebagian besar mahasiswa masih mengalami kesulitan dalam menyelesaikan soal pemahaman. Sebanyak $77 \%$ dari sampel penelitian belum paham cara menyelesaikan soal. Berdasarkan data tersebut maka dapat disimpulkan bahwa mahasiswa belum dapat mengoptimalkan seluruh kemampuan terutama kemampuan pemahaman matematisnya dalam mengerjakan soal teori bilangan sehingga cenderung menyerah dalam mengerjakan soal ketika mengalami kesulitan. Sebanyak 23\% sampel sudah mengerti cara menyelesaikan namun masih beberapa yang kurang tepat dalam langkah penyelesaiannya. Hal ini disebabkan oleh beberapa faktor, salah satunya adalah lemahnya pemahaman dalam membedakan bilangan rasional dengan irasional beserta definisi dan sifat-sifatmya (materi prasyarat).
\end{abstract}

Kata kunci: Kemampuan Pemahaman Matematis, Teori Bilangan

\begin{abstract}
Lack of student understanding of the concepts given and students still have difficulty in identifying what is known and what will be proven. This study aims to analyze students' mathematical comprehension skills in the number theory course. The research methodology used was using qualitative deductive research method. Research subjects used in this study amounted to 30 respondents. Data collection techniques used literature study, documentation and interviews. The result of research of mathematical understanding ability from two research indications is conceptual comprehension ability and functional comprehension ability, most of student still difficulties in solving comprehension problem. As many as $77 \%$ of the research sample has not understood how to solve the problem. Based on these data it can be concluded that the student has not been able to optimize all the ability, especially the ability of mathematical understanding in working on the number theory theory that tends to give up in working on problems when experiencing difficulties. As many as 23\% of the sample already understand how to solve but still some less precise in step settlement. This is due to several factors, one of which is the lack of understanding in distinguishing rational numbers with irrational ones along with their definitions and qualities (prerequisite materials).
\end{abstract}

Keywords: Ability of Mathematical Understandin, number theory

DOI: http://dx.doi.org/10.15575/Analisa.xxx.xxx

Received: xxxxxx ; Accepted: xxxxxx ; Published: $x x x x x x$ 


\section{PENDAHULUAN}

Pembelajaran merupakan suatu kegiatan yang melibatkan berbagai aspek seperti guru atau dosen, siswa atau mahasiswa, dan situasi belajar yang sedang berlangsung. Pembelajaran memiliki karakteristik proses mental dan proses kontrutivisme dalam membangun pengetahuan (Sagala, 2010). Adapun komponen penunjang dalam pelaksanaan pembelajaran di perguruan tinggi adalah kualitas berpikir dan pemahaman mahasiswa, kemampuan pengajar, strategi yang digunakan, media penunjang, sasaran dan tujuan pembelajaran yang akan dicapai. Proses pembelajaran akan berjalan optimal apabila interaksi antara komponen yang terkait berjalan dengan baik.

Matematika merupakan proses bernalar, pembentukan karakter dan pola berfikir, pembentukan sikap objektif, jujur, sitematis, kritis dan kreatif serta sebagai ilmu penunjang dalam pengambilan suatu kesimpulan (Wanti, 2017). Dari pendapat diatas dapat dimaknai matematika memiliki peran yang sangat penting dalam kehidupan kita dengan adanya matematika dapat mentuk karakter dan pola berpikir secara objektif. Dengan kita mempelajari matematika kita akan belajar jujurr dalam menetukan suatu perhitungan yang akan disajikan secara sistematis untuk mengambil suatu kesimpulan secara tepat.

Dalam pembelajaran matematika, pemahaman matematis merupakan kemampuan yang sangat penting dan harus dimiliki oleh mahasiswa. Kemampuan pemahaman matematis adalah salah satu tujuan penting dalam pembelajaran, memberikan pengertian bahwa materi-materi yang diajarkan kepada mahasiswa bukan hanya sebagai hafalan, namun lebih dari itu dengan pemahaman mahasiswa dapat lebih mengerti akan konsep materi perkuliahan itu sendiri. Pemahaman matematis juga merupakan salah satu tujuan dari setiap materi yang disampaikan oleh dosen, sebab dosen merupakan pembimbing mahasiswa untuk mencapai konsep yang diharapkan.

Dahlan (Mulyati, 2016) mengungkapkan hampir semua teori belajar menjadikan pemahaman sebagai tujuan dari pembelajaran. Senada dengan itu menurut Syarifah dalam JPPM (2017) pemahaman matematis merupakan suatu tujuan dalam pembelajaran matematika. Pemahaman matematis sebagai suatu tujuan, dapat dimaknai suatu kemampuan memahami konsep, membedakan sejumlah konsep-konsep yang saling terpisah, serta kemampuan melakukan perhitungan secara bermakna pada situasi atau permasalahan-permasalahan yang lebih luas. Demikian pula, pemahaman matematis merupakan landasan penting untuk berpikir dalam menyelesaikan persoalan maupun masalah dalam matematika. Selain itu, kemampuan pemahaman matematis akan mendukung terhadap pengembangan kemampuan matematis lainnya, seperti komunikasi, representasi, pemecahan masalah, koneksi, berpikir kritis, serta kemampuan matematis lainnya. Artinya adalah, jika seseorang memiliki kemampuan pemahaman matematis yang optimal, maka kemampuan matematis lain juga bisa dikembangkan dan dikuasai dengan baik.

Terdapat tiga macam pemahaman matematis yaitu: 1) Pemahaman translasi (pengubahan), mulai dari terjemahan dalam arti yang sebenarnya, bentuk lain dan pemberian makna dari berbagai macam variasi yang berbedabeda. 2) Pemahaman interpolasi, yakni menghubungkan informasi-informasi terdahulu dengan yang diketahui berikutnya dari sebuah ide, atau menghubungkan beberapa bagian dari beberapa teorema dari bacaan bukan hanya dengan kata-kata dan frase. 3) Pemahaman ekstrapolasi. Dengan ekstrapolasi diharapkan seseorang mampu melihat di balik yang tertulis, dapat membuat ramalan tentang konsekuensi atau dapat memperluas presepsi dalam arti waktu, dimensi, kasus, ataupun masalahnya (Sujana, 2012). 
Indikator kemampuan pemahaman matematis yang digunakan adalah menurut pendapat Polatttsek (dalam Hendriana dkk, 2017), membedakan dua jenis pemahaman, yaitu: (1) Pemahaman komputasional, yaitu dapat menerapkan konsep atau rumus pada perhitungan rutin atau sederhana, atau mengerjakan sesuatu secara algoritmik saja; (2) Pemahaman fungsional yaitu dapat mengaitkan suatu konsep dengan konsep lainnya secara benar dan menyadari proses yang dilakukan.

Teori Bilangan merupakan mata kuliah wajib ditempuh oleh mahasiswa Program Studi Pendidikan Matematika di Universitas Indraprasta PGRI Jakarta. Teori Bilangan merupakan materi perkuliahan yang tersturuktur secara hierarkis, maksudnya bahwa mata kuliah teori bilangan merupakan dasar bagi mata kuliah selanjutnya. Mata kuliah ini dibahas mengenai beberapa konsep dasar dan penting dalam teori bilangan. Mata kuliah ini juga memberikan wahana kepada mahasiswa untuk berlatih berpikir kreatif dalam menyelesaikan suatu permasalahan dalam teori bilangan dengan mengacu sasaran di atas. Mata kuliah ini diberikan dengan menekankan pada pemberian waktu yang relatif banyak kepada mahasiswa untuk melakukan problem solving mulai dari permasalahan sederhana hingga yang cukup rumit.

Teori bilangan adalah cabang dari matematika di mana yang dipelajari adalah sifat dan hubungan antara beberapa tipe bilangan. Semesta pembicaraan dalam Teori Bilangan yang paling penting adalah himpunan bilangan bulat positif (Z). Sebagai salah satu cabang matematika, teori bilangan dapat disebut sebagai "Aritmetika Lanjut (Advanced Arithmetics)". Dalam teori bilangan terdapat beberapa bagian yang dipelajari berhubungan dengan bilangan bulat yaitu diantaranya: bilangan prima (prime numbers), teorema fundamental aritmetika (fundamental theory of arithmetic), kongruensi (congruences) dan uji-uji keprimaan (primality test). Setelah menempuh mata kuliah ini, mahasiswa diharapkan dapat meningkatkan kemampuan bereksplorasi, berargumentasi, melakukan koneksi, berkomunikasi dan kemampuan problem solving melalui pemahaman konsep teori bilangan.

Bedasarkan hasil pengamatan, khususnya selama mengajarkan mata kuliah Teori bilangan, umumnya mahasiswa mengalami kesulitan karena: 1) kurangnya pemahaman mahasiswa terhadap konsep yang akan dibuktikan, mereka masih mengalami kesulitan dalam mengidentifikasi apa yang diketahui, apa yang akan dibuktikan; (2) kurangnya pemahaman tentang metode-metode pembuktian yang akan digunakan; (3) kurangnya kemampuan dalam menggunakan maupun memanipulasi fakta-fakta yang diketahui dan mengkaitkannya dengan yang akan ditunjukkan serta; (4) kurangnya kemampuan dalam menyusun alur/sistematika bukti tersebut.

Berdasarkan hasil wawancara dengan mahasiswa, sebagian mahasiswa mengganggap materi perkuliahan teori bilangan adalah matakuliah yang sulit dikarnakan: 1) memiliki banyak teorema dan sifat yang harus dihafal, ada beberapa teorema yang mirip atau serupa sehingga sering tertukar; 2) materi teori bilangan dianggap abstrak sehingga sulit dipahami; 3) soal-soalnya juga membinggungkan. Melihat rendahnya kemampuan pemahaman konsep, maka perlu dianalisis terkait kemampuan mahasiswa dalam kedua hal tersebut. Karena itu perlu diperoleh data akurat penyebab kesulitan mahasiswa dalam memahami konsep teori bilangan. Hal ini penting untuk merancang pembelajaran matematika secara efektif. Dalam penelitian ini peneliti mengambil materi pokok bahasan bilangan bulat, dikarenakan didalam bilangan bulat terdapat sifat, dan teorema yang berlaku dan tidak berlaku di bilangan asli dan bilangan cacah. Dari permasalahan di atas peneliti akan melakukan penelitian dengan judul: analisis kemampuan pemahaman pada mata kuliah teori bilangan. 


\section{METODE PENELITIAN}

Tempat pelaksanaan penelitian ini dilakasanakan di Universitas Indraprasta PGRI Jakarta pada mata kuliah Teori Bilangan yang diajarkan di semester 3 tahun akademik 2017/2018. Penelitian ini dilaksanakan selama empat bulan dari bulan Oktober 2017 sampai dengan bulan Januari 2018.

Metode yang digunakan dalam penelitian ini adalah metode penelitian deskriptif kualitatif. Sukardi (dalam Syarifah, 2017) menyatakan bahwa penelitian deskriptif merupakan penelitian yang menggambarkan aturan atau mengiterpretasikan objek sesuai dengan apa adanya. Dalam penelitian ini ingin diungkapkan kemampuan pemahaman matematis mahasiswa dalam mata kuliah teori bilangan. Penelitian kualitatif merupakan penelitian yang digunakan untuk menyelidiki, menemukan, menggambarkan, dan menjelasakan kualitas atau keistimewaan dari pengaruh sosial yang tidak dapat dijelaskan, diukur, atau digambarkan melalui pendekatan kuantitatif (Saryono, dalam Syarifah:2017). Adapun subjek dalam penelitian ini adalah mahasiswa semester tiga sebanyak 1 kelas yang terdiri dari 30 mahasiswa.

Teknik pengumpulan data menggunakan triangulasi data yaitu: 1 . Studi pustaka dalam hal ini peneliti mengumpulkan informasi diantarannya dari berbagai sumber seperti: indikator kemampuan pemahaman, buku referensi, data dari internet, artikel ilmiah 2. Dokumentasi dalam hal ini peneliti mengumpulkan soal dan jawaban teori bilangan mahasiswa pada Ujian Tengah Semester tahun akademik 2017/2018, penelitian yang relevan seperti skripsi, jurnal, tesis dan disertasi. 3. Wawancara dalam penelitian ini yang menjadi narasumber adalah para ahli. Topik yang akan ditanyakan adalah mengenai teknik menentukan indikator dalam penelitian.
Teknik analisis data adalah prosedur pada proses penelitian untuk menjadikan data yang telah diperoleh disusun menjadi sebuah data yang siap disajikan. Adapun langkah-langkah dalam menganalisis data penelitian dapat diuraikan sebagai berikut:

\section{Analisis Karakteristik Responden}

Cara yang digunakan dalam menganalisis karakteristik responden yaitu dengan cara mengelompokkan jenis kelamin laki-laki dan perempuan.

2. Analisis kemampuan Pemahaman Matematis

Cara yang digunakan dalam menganalisis kemampuan pemahaman matematis yaitu dengan cara menyesuaikan soal dengan indikator. Soal dan jawaban ujian tengah semester mahasiswa pada mata kuliah teori bilangan diperiksa apakah pengerjaan mahasiswa sudah benar dan juga sesuai dengan indikator yang ada. Berikut ini adalah tabel indikator kemampuan pemahaman matematis, yaitu:

Tabel 1 Indikator Kemampuan Pemahaman

\begin{tabular}{|c|c|}
\hline Indikator & Butir Soal \\
\hline $\begin{array}{l}\text { Pemahaman } \\
\text { Komputasional } \\
\text { Menerapkan } \\
\text { definisi dari } \\
\text { bilangan rasinal } \\
\text { pada bilangan } \\
\text { decimal berulang } \\
\text { secara sederhana. }\end{array}$ & $\begin{array}{l}\text { Buktikan bahwa pecahan } \\
0,2531243124312 \text {... meru } \\
\text { pakan bilangan rasional! }\end{array}$ \\
\hline $\begin{array}{l}\text { Pemahaman } \\
\text { fungsional } \\
\text { Mengaitkan } \\
\text { sesuatu dengan hal } \\
\text { lainnya dan } \\
\text { menyadari proses }\end{array}$ & $\begin{array}{l}\text { Seorang karyawan } \\
\text { diminta untuk membeli } \\
\text { dua jenis kue oleh } \\
\text { atasannya yang harganya } \\
\text { masing-masing } \$ 19 \text { dan } \\
\$ \text { 80. Atasannya memberi }\end{array}$ \\
\hline
\end{tabular}




\begin{tabular}{|l|l|}
\hline yang dilakukan & uang sebesar \$ 1980 \\
& untuk membelanjakan \\
kedua jenis kue tersebut. & Tentukan salah satu \\
kombinasi yang mungkin \\
dibeli oleh pegawai \\
tersebut!
\end{tabular}

Sumber: Polattsek (dalam Herdiana dkk, 2017) dengan Modifikasi

\section{HASIL DAN PEMBAHASAN}

Gambaran analisis butir soal tidak terlepas dari karakteristik responden. Karakteristik responden disini dipandang dari segi jenis kelamin. Secara keseluruhan deskripsi dari karakteristik responden mahasiswa matematika dapat dilihat pada diagram 1.

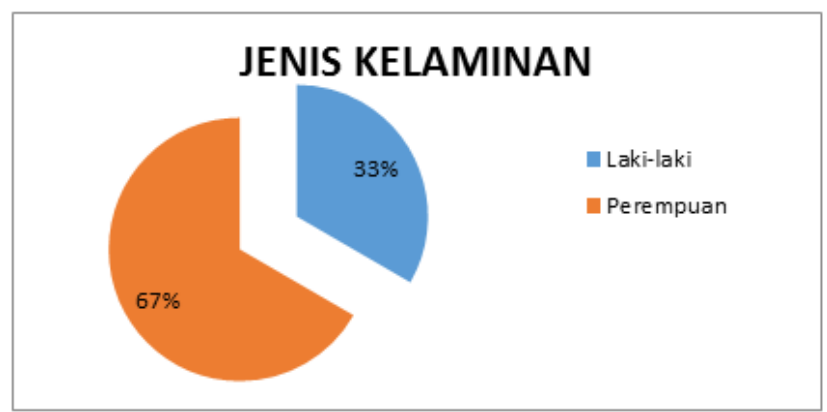

\section{Diagram 1 Persentase Berdasarkan Jenis Kelamin}

Diagram 1 menunjukkan bahawa jumlah responden berjenis kelamin perempuan sebesar 20 orang atau 67\%, sedangkan responden yang berjenis kelamin laki-laki sebanyak 10 orang atau 33\%.

Analisis kemampuan pemahaman matematis dapat dipandang melalui ketepatan dalam pengerjaan soal, kemampuan pemahaman matematis berdasarkan indikator dan membandingkan jawaban yang ada dalam kunci dengan beberapa pengerjaan mahasiswa. Dapat dilihat pada diagram 2.

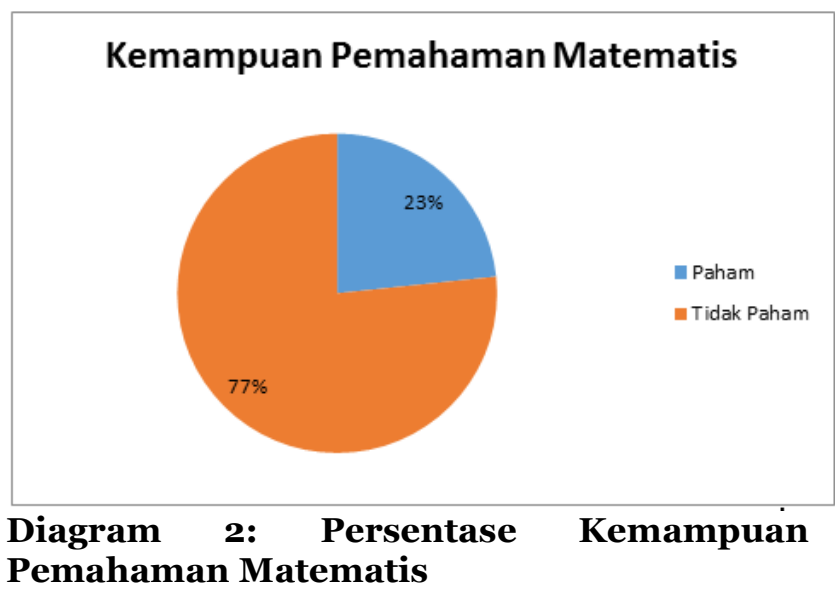

Analisis pemahaman matematis pada mata kuliah teori bilangan disajikan pada diagram 2 persentase tingkat kemampuan pembuktian matematis mahasiswa. Pada diagram 2 tersebut, sebanyak 77\% dari sampel penelitian belum paham cara menyelesaiakan soal. Berdasarkan data tersebut maka dapat disimpulkan bahwa mahasiswa belum dapat mengoptimalkan seluruh kemampuan terutama kemampuan pemahaman matematisnya dalam mengerjakan soal teori bilangan sehingga cenderung menyerah dalam mengerjakan soal ketika mengalami kesulitan. Sebanyak 23\% sampel sudah mengerti cara menyelesaikan namun masih beberapa yang kurang tepat dalam langkah penyelesaiannya.

Analisis kemampuan pemahaman matematis berdasarkan jenis kelamin yang dipandang dalam kesesuaian dalam menjawab soal kemampuan pemahaman matematis dapat dilihat pada diagram 3 .

Pemahaman Matematis Berdasarkan Jenis Kelamin

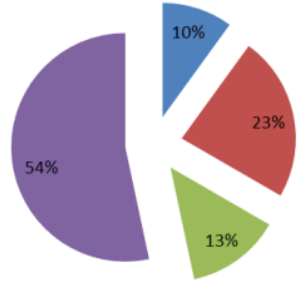

- Laki-Laki (Paham) - Laki-Laki (Tidak Paham) = Perempuan (Paham) - Perempuan (Tidak Paham) 


\section{Diagram 3 Persentase Kemampuan Pemahaman Matematis Berdasarkan Jenis Kelamin}

Analisis kemampuan pemahaman matematis berdasarkan jenis kelamin disajian pada diagram 3, persentase tingkat kemampuan pembuktian matematis mahasiswa laki-laki yang sudah memahami cara menyelesaikan soal sebanyak $10 \%$ atau berjumlah 3 responden dan mahasiswa laki-laki yang belum memahami cara menyelesaian soal sebanyak $23 \%$ atau sebanyak 7 responden. Selanjutnya, persentase tingkat kemampuan matematis mahasiswa perempuan yang sudah memahami cara menyelesaikan soal sebanyak $13 \%$ atau 4 responden dan sebanyak $54 \%$ atau 16 resenponden mahasiswa perempuan belum dapat menyelesaikan soal. Berdasarkan data tersebut dapat disimpulkan adanya perbedaan kemampuan pemahaman matematis mahasiswa laki-laki dan mahasiswa perempuan. Jika diperhatikan dari persentase diperoleh kemampuan pemahaman matematis mahasiwa laki-laki lebih unggul dari mahasiswa perempuan pada mata kuliah teori bilangan. Pada penelitian ini mahasiswa perempuan cenderung kurang teliti dan kurang paham dalam menyelesaikan soal, dan beberapa mahasiwa perempuan mengalami kesulitan serta beberapa dari mereka menggunakan jawaban pintas dalam mengerjakan soal. Sesuai dengan pendapat Lestari (2017) Bagi yang menganggap matematika menyenangkan maka akan tumbuh motivasi dalam diri untuk mempelajari matematika dan optimis dalam menyelesaikan masalah-masalah yang bersifat menantang dalam pembelajaran matematika. Sebaliknya, bagi yang menganggap matematika sebagai pelajaran yang sulit, maka akan bersikap pesimis dalam menyelesaikan masalah matematika dan kurang menyukai pelajaran matematika.

Kemampuan pemahaman matematis terbagi menjadi dua indikator yakni:

1. Kemampuan Pemahaman Komputasional
Kemampuan pemahaman komputasi yaitu dapat menerapkan konsep atau rumus pada pertemuan rutin/sederhana, atau mengerjakan sesuatu algortmik. Berikut diberikan soal dan cara penyelesaian serta beberapa hasil jawaban tes dari mahasiswa yang terkait dengan kemampuan pemahaman matematis pada mata kuliah teori bilangan. Soal dan jawaban dari tes yang diberikan adalah:

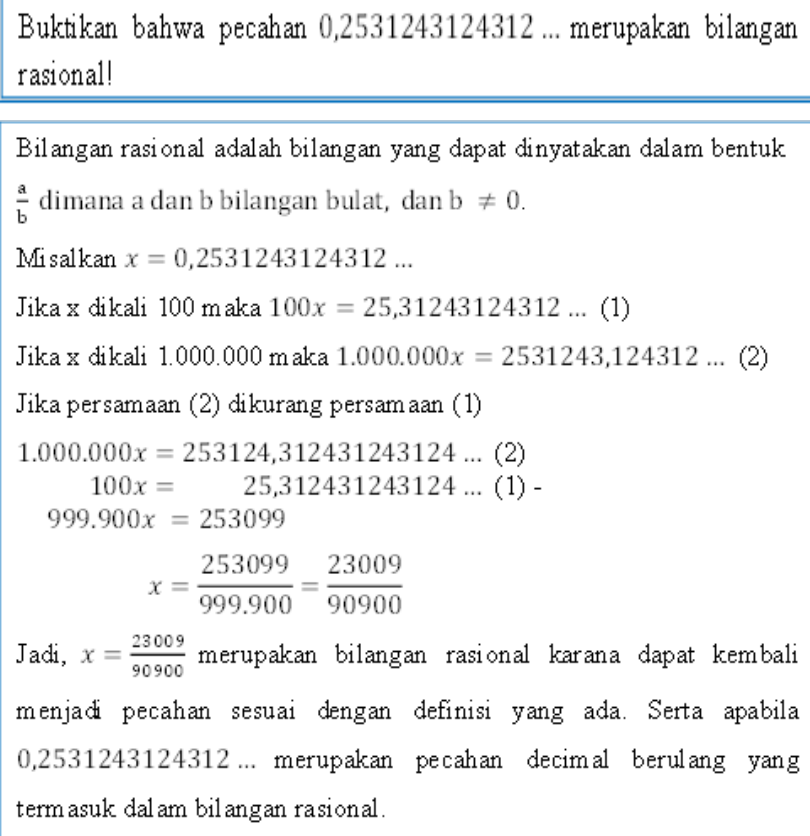

Pengerjaan yang diberikan oleh dosen tanpa memahami maksud dari langkah-langkah pengerjaan yang disampaikan. Sehingga dalam soal ujian tengah semester yang diberikan mahasiswa tidak bisa mengerjakan soal yang tidak sesuai dengan contoh yang diberikan. Seharusnya mahasiswa dapat mengidentifikasi pola decimal berulang baru diselesaikan. Seperti pada Gambar 1 berikut:

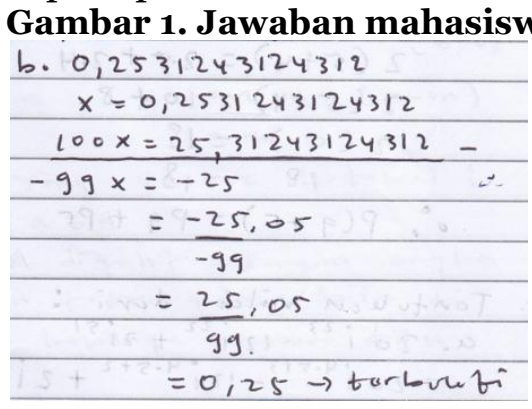


Selanjutnya, mahasiswa kedua sudah dapat memahami konsep yang diberikan oleh dosen. Dengan memisalkan terlebih dahulu suatu bentuk decimal berulang dan selanjutnya mengalikan permisalan dengan menyamakan angka di belakang koma. Seperti pada Gambar 2 berikut:

Gambar 2 Jawaban Mahasiswa 2

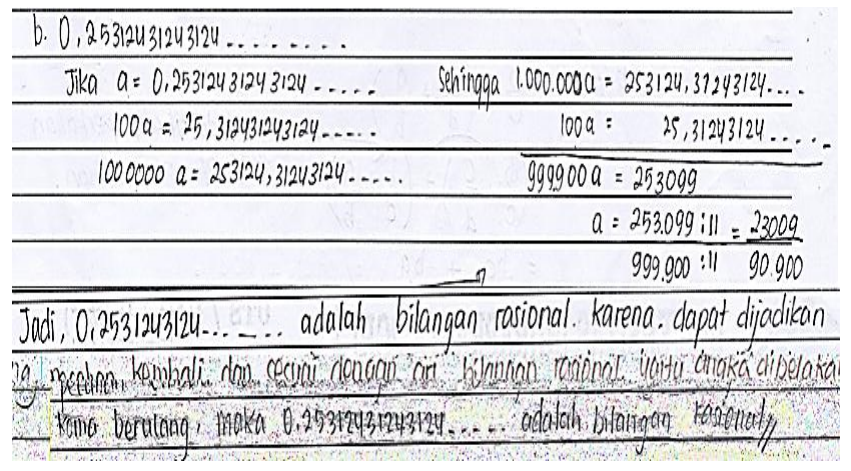

Pada Gambar 2 jawaban mahasiswa sudah dapat menerapkan konsep yang diberikan oleh dosen. Jawaban dari mahasiswa menunjukkan bahwa mahasiswa tersebut sudah dapat mengidentifikasi pola desimal berulangnya, mengubah suatu bentuk representasi ke bentuk lainnya dengan mengalikan permisalan dengan seratus dan satu juta dan dapat menyimpulkan sifat-sifat suatu konsep dan mengenal syarat yang menetukan suatu konsep.

\section{Kemampuan Pemahaman Fungsional}

Kemampuan pemahaman fungsional yaitu dapat mengaitkan suatu konsep dengan konsep lainnya secara benar menyadari proses yang dilakukan. Berikut diberikan soal dan cara penyelesaian serta beberapa hasil jawaban tes dari mahasiswa yang terkait dengan kemampuan pemahaman matematis pada mata kuliah teori bilangan. Soal dan jawaban dari tes yang diberikan adalah:

Seorang karyawan diminta untuk membeli dua jenis kue oleh atasannya yang harganya masing-masing $\$ 19$ dan $\$ 80$. Atasannya memberi uang sebesar $\$ 1980$ untuk membelanjakan kedua jenis kue tersebut. Tentukan salah satu kombinasi yang mungkin dibeli oleh pegawai tersebut!

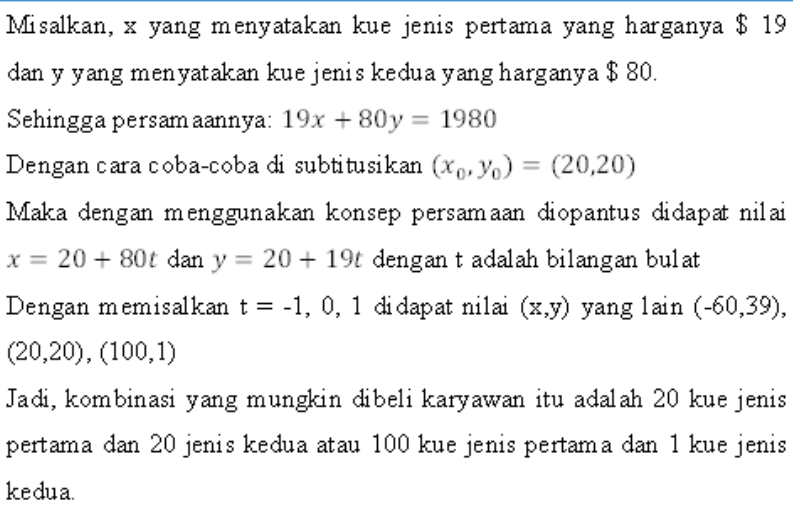

Jadi, kombinasi yang mungkin dibeli karyawan itu adalah 20 kue jenis pertama dan 20 jenis kedua atau 100 kue jenis pertama dan 1 kue jenis kedua.

Dapat diperhatiakan pengerjaan mahasiswa yang pertama,untuk menetukan persamaan awal yaitu 19x $+80 y=1980$ sudah menjawab dengan benar walaupun tidak membuat permisalan terlebih dahulu. Selanjutnya dalam pengerjaan langkah yang digunakan menggunakan algorima Euclid, tetapi penyelesaian akhirnya kurang tetpat karena apabila disubtitusikan nilai $\mathrm{x}$ dan $\mathrm{y}$ nya dan dijumlahkan tidak sama dengan 1980. Seperti pada Gambar 3 berikut:

\section{Gambar 3. Jawaban mahasiswa 3}

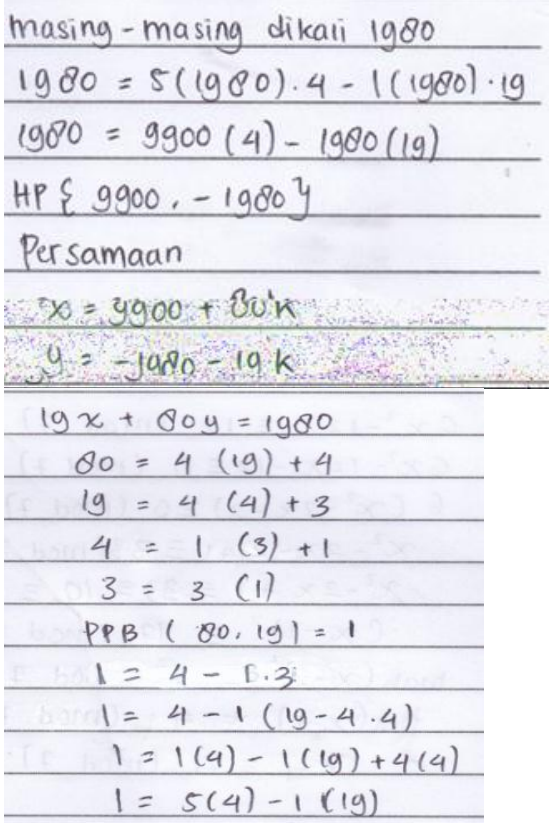


Selanjutnya, mahasiswa kedua sudah dapat memahami konsep yang diberikan oleh dosen. Dengan membuat persamaan yang sesuai dengan yang dimaksud pada soal walaupun masih tidak memberi keterangan untuk permisalan variable $\mathrm{x}$ dan $\mathrm{y}$ nya. Pada pengerjaan mahasiswa yang ke dua ini menggunakan permisalan $\mathrm{x}=100$ dan $\mathrm{y}=1$. Ini adalah permisalan yang tepat karena apabila disubtitusikan nilai $\mathrm{x}$ dan y kepersamaan yang ada akan menghasilkan jumlah yang sama. Pada bagian akhir pengerjaan mahsiswa kedua ini tidak membuat kesimpulan yang menyatakan kombinasi yang mungkin hanya ada dua yaitu $(20,20)$ dan $(100,1)$. Seperti pada Gambar 4 berikut :

\section{Gambar 4. Jawaban mahasiswa 4}

a.) $19 x+80 y=1980$
dengan cara coba ${ }^{2} 19(100)+80(1)=1980$ maka $x_{0}=100 \quad y_{0}=1$
$x=x_{0}+b t \rightarrow x=100+80 t$
$y=y_{0}-a t \rightarrow y=1-19 t$
maka untuk $x_{0}$ dan $y_{0}($ ainnya: $(20,20),(100,1),(180,-18)$.
$t=-1 \rightarrow x=100+80(-1)=20, \quad y=1-19(-1)=20$,
$t=-1 \rightarrow(20,20)$
$t=0 \rightarrow x=100+80(0)=100, \quad y=1-19(0)=1$
$t=0 \rightarrow(100,1), \quad y=1-19(1)=-18$
$t=1 \rightarrow x=100+80(1)=180, \quad y(180,-18)$.

Pada Gambar 4 jawaban mahasiswa sudah dapat menerapkan konsep yang diberikan oleh dosen. Jawaban dari mahasiswa menunjukkan bahwa mahasiswa tersebut sudah dapat mengaitkan suatu konsep dengan konseplainnya dengan tepat dan selanjutnya dapat meneruskan konsep dengan sadar dan sesuai dengan langkah-langkah pengerjaan.

Namun, jika dilihat kembali dari persentase kemampuan pemahaman matematis pada Diagram 2, masih didapatkan hasil yang belum optimal. Terlihat bahwa sebagian besar mahasiswa masih mengalami kesulitan dalam menyelesaikan soal pemahaman. Hal ini disebabkan oleh beberapa faktor, salah satunya adalah lemahnya pemahaman dalam membedakan bilangan rasional dengan irasional beserta definisi dan sifat-sifatmya (materi prasyarat). Banyaknya sifat-sifat pada teori bilangan kadang membuat mahasiswa bingung, sifat atau teorema mana yang harus digunakan sesuai dengan soal yang ditanyakan. Hal ini dikarenakan keterbatasan pemahaman mahasiswa terhadap materi tersebut. Berdasarkan uraian di atas terlihat bahwa kemampuan pemahaman matematis mahasiswa pada Mata Kuliah Teori Bilangan secara umum masih perlu ditingkatkan lagi.

\section{KESIMPULAN}

Berdasarkan pembahasan, maka dapat disimpulkan bahwa:

Sebagian besar mahasiswa masih mengalami kesulitan dalam menyelesaikan soal pemahaman. Sebanyak $77 \%$ dari sampel penelitian belum paham cara menyelesaikan soal. Berdasarkan data tersebut maka dapat disimpulkan bahwa mahasiswa belum dapat mengoptimalkan seluruh kemampuan terutama kemampuan pemahaman matematisnya dalam mengerjakan soal teori bilangan sehingga cenderung menyerah dalam mengerjakan soal ketika mengalami kesulitan. Sebanyak 23\% sampel sudah mengerti cara menyelesaikan namun masih beberapa yang kurang tepat dalam langkah penyelesaiannya. Hal ini disebabkan oleh beberapa faktor, salah satunya adalah lemahnya pemahaman dalam membedakan bilangan rasional dengan irasional beserta definisi dan sifat-sifatmya (materi prasyarat).

\section{DAFTAR PUSTAKA}

Hendriana, Heris dkk. (2017). Hard Skills and Soft Skills. Bandung: Aditama.

Mulyati. 2016. Peningkatan Kemampuan Pemahaman dan Representasi Matematis Siswa SMA Melalui Strategi Preview-Question-Read- 
Reflect-Recite-Review. Jurnal Analisa Vol. 2 No. 3.

Sagala, Syaiful. (2010). Konsep dan Makna Pembelajaran. Bandung: Alfabeta.

Sujana, Nana.2012. Penilaian Hasil Proses Belajar Mengajar.Bandung:PT Remaja Rosdakarya.

Syarifah, Lely Lailatus. 2017. Analisis Kemampuan Pemahaman Matematis Pada Mata Kuliah Pembelajaran Matematika SMA II. JPPM Vol, 10 No. 2

Wanti, Nopia dkk. 2017. Pembelajaran Induktif Pada Kemampuan Penalaran Matematis dan Self-Regulated Learning Siswa. Jurnal Analisa Vol. 3 No. 1.

Lestari, Witri. 2017. Pengaruh Kemampuan Awal Matematika dan Motivasi Belajar terhadap Hasil Belajar Matematika. Jurnal Analisa Vol. 3 No. 1 . 